\title{
Introduction to the Special Issue: Exploring Gender and Sikh Traditions
}

\author{
Doris R. Jakobsh
}

Citation: Jakobsh, Doris R. 2021. Introduction to the Special Issue: Exploring Gender and Sikh Traditions. Religions 12: 161. https:/ / doi.org/10.3390/rel12030161

Received: 18 February 2021 Accepted: 23 February 2021 Published: 2 March 2021

Publisher's Note: MDPI stays neutral with regard to jurisdictional claims in published maps and institutional affiliations.

Copyright: (C) 2021 by the author. Licensee MDPI, Basel, Switzerland. This article is an open access article distributed under the terms and conditions of the Creative Commons Attribution (CC BY) license (https:/ / creativecommons.org/licenses/by/ $4.0 /)$.
Department of Religious Studies, University of Waterloo, Waterloo, ON N2L 3G1, Canada; djakobsh@uwaterloo.ca

Gender analysis has not received a great deal of attention within Sikh Studies (Jakobsh 2003). On the other hand, a small number of scholars have spent years, sometimes decades, exploring issues under the rubric of "women and/in Sikhism". Nikky-Guninder Kaur Singh's $(1993,2005)$ ground-breaking work immediately comes to mind in terms of flinging open wide the doors to feminist approaches in Sikh Studies. Sikhism and Women. History, Text, Experience (Jakobsh 2010) was an important milestone in bringing together varied voices to address the paucity of scholarship in this area. The primary task at that point in time was locating scholars who were sufficiently engaged in the study of women and Sikhism to contribute to the project. Over the past decade, research on women and the feminine within Sikh Studies has grown. As an important part of these developments, scholarly inquiry has increasingly come to recognize that the category "woman" is problematic. "Woman" is not unitary, differences clearly exist in terms of inequalities (Brah 1991). Moreover, as many of the chapters in this volume demonstrate, Sikh feminisms are also emerging. This is evident in the deepening and increasing rigorous of theoretical and methodological approaches in scholarship. Paradigm shifts are coming to the fore, as in, for example, feminist-inspired Sikh activism.

However, similar to transitions within academia at large that have seen the need to replace Women's Studies departments with Gender Studies, it has seemed appropriate, even necessary, to move from a somewhat singular 'women's focus' to one of gender vis-à-vis the study of Sikhism. The transition from women's studies to gender studies also reflects changes in the ways in which issues of gender and sexuality have been woven into interdisciplinary studies. Gender studies invite a broader, more inclusive range of identities beyond the traditional binary of 'male' and 'female'. In other words, an understanding of gender as socially constructed invites analysis of a spectrum of gender identities. This Special Issue includes an examination of masculinity and male bodies, for they too are built and constructed on social systems, cultural and religious beliefs, and myths.

Gender studies, in line with women's, masculine and feminist studies, generally begin with a deconstruction of patriarchy, identifying subordinate-dominant relations and structures between individuals. It does so within an understanding that there are numerous forms of discrimination and power structures that concurrently create a multiplicity of oppression. The feminist theologian Elisabeth Schüssler Fiorenza (1990) identifies this complexity of inegalitarian structures as 'historical interstructuring'. Kimberle Crenshaw (1991) delineates a similar, but even wider-ranging notion of 'intersectionality' to address the many layers and often simultaneous forms of oppression, alongside the pervasive power structures that create these forms of subjugation. Intersectionality has become the basis of an increasingly systematized production of contemporary discourses on feminism and gender analysis, as shall be seen in varied contributions in this volume.

Further and indicative of the raison d'être of this Special Issue, the intersectional spaces of gender and religion are also in need of examination, based on an understanding that religions too are socially constructed. Far from being sui generis, static and homogeneous entities, as far too often portrayed in world religions textbooks, religious traditions instead 
are constantly and consistently changing in response to historical, cultural, and social contexts. Religion itself is best understood as "mediated, administered, lived, contested and adapted by socially situated agents, just like other forms of culture-and in relation to them" (Bailey and Redden 2011, p. 3). From this perspective, when "the" Sikh religious tradition is examined in terms of practices, ideologies, rituals, notions of identity-both historically and within the contemporary milieu-we can only conclude that "a" Sikh tradition does not exist. Instead, there are numerous forms thereof as this contestation and process of adaptation takes place. For this reason, Sikhism in this volume is presented as "Sikh traditions" or "Sikhisms".

When I initially sent out an informal "call" to fellow scholars in Sikh Studies about a potential Special Issue of Religions, potentially entitled "Exploring Gender and Sikh traditions," the responses were overwhelmingly positive. To effectively understand difference, social relations and inegalitarian structures vis-à-vis Sikh traditions, I invited contributions from a wide range of disciplinary and creative theoretical approaches to Sikhs and gender construction. Furthermore, I put forward that this venture would offer the opportunity to move beyond traditional and historically primary foci of the study of Sikhism, namely, textual/scriptural study, philosophy and theology, and turn instead to what has, at least with regard to Sikh Studies, been vastly understudied and often misunderstood - that which is often identified as "lived religion". The notion of lived religion and here, "lived Sikhisms", allows for an expansion of what is understood as religion, religiosity, piety and devotion, in order to pay greater attention to everyday practices, narratives, and performances as they address the complexity and multiplicity of "being" Sikh; in other words, what Sikhs are "doing" in all manner of variance, as opposed to what the texts are "saying". Moreover, with a shift in focus from the predominance of the text, scholars can more readily attend to materiality, gender, sexuality, senses, the body, power relations and other material conditions (Chidester 2000). Lived religion moves from binary oppositional understandings of what constitutes "the secular" and "the religious", including what Hall identifies as "tensions and the ongoing struggle of definition." Practices or religious performances bear the "marks of both regulation and what, for want of a better word, we may term resistance" (Hall 1997, pp. viii-ix). Resistance is a priori to gender and feminist analysis, as is the notion of agency in understanding how oppressive systems, including religions, are confronted, and challenged, whether as patriarchy or beyond. New ways of conceptualizing religion include a necessary critique of the privileging of belief systems over practices, stemming closely from notions of colonial, European and Christian exceptionalism. Moving toward more fluid religious boundaries, without rejecting the traditional historical, theoretical, and textual approaches that have largely defined Sikh Studies, invites counterhegemonic visions of what constitutes religions and/or Sikhisms.

In the original call for papers for this Special Issue of Religions, each contributor was asked to consider the following questions: How has gender been constructed within Sikh traditions? How is gender being constructed within historical or contemporary Sikhisms? Over the next year, a diverse group of scholars from across the globe answered these queries with a wide range of intellectually stimulating, challenging and sometimes deeply personal responses. Some of the scholars in this issue have already made significant contributions to the study of Sikhisms, women and gender studies. However, a good number of contributors are emerging scholars within Sikh Studies. Overall, there is a significant diversity in terms of disciplinary and theoretical approaches, alongside geographical locales.

\section{Ethnographic Perspectives}

This Special Issue begins with scholarship based on ethnography. Ethnographic approaches, though categorically diverse, generally include a focus on meaning-making in the process of learning about, in this case, "religious people" (Sikhs), as opposed to simply "studying" religious people. As such, ethnographic studies encourage creative frameworks to understand the intersections of gender construction and lived religion. Toril Moi (2015) has warned against approaches within feminist studies (and gender studies, one could add) 
becoming excessively abstract, bogged down by over-theorizing and overgeneralizingin essence, no longer applying or relating to individuals' lived realities and concrete experiences. As many of the studies in this issue show, ethnography is particularly suited to explore and describe what is taking place in ordinary people's lives.

A central aspect that comes to the fore in this issue is that of agency-agency in the construction and reconstruction of roles, attitudes, and practices as they pertain to Sikh traditions. Kamal Arora's work, opening this section, examines religious expression and piety in a Delhi gurdwara known as Shaheedganj Gurdwara in Tilak Vihar, the "widow's colony" in West Delhi. Tilak Vihar became a place of refuge for surviving wives of the approximately $3500 \mathrm{Sikh}$ males who were routinely killed after the assassination of Prime Minister Indira Gandhi by her Sikh bodyguards. Shining a light on the complexity of gender and religion, Arora examines the male-administered Sikh space that has over time become a primarily female place, a "gendered counterpublic", a space that allows these survivors to cope with the continuing confrontation of loss and trauma in their daily lives through gendered devotional practices, upholding memory and healing.

Italian scholar Barbara Bertoloni focuses on gendered practices within Italian gurdwaras through the Sikh lens of "seva", or service. To contextualize the issues discussed, she gives an overview of Sikhs in Italy, the largest Sikh community in Europe outside of UK numbers. Highlighting "official" and "unofficial" gendered roles and practices in gurdwaras, Bertoloni examines notions such as "izzat" or honor, as well as the rigid divisions of labour within Sikh families that reproduce degrees of power between genders.

Sandra Santos-Fraile's anthropological and ethnographic exploration of Sikh communities in Barcelona concentrates on the gendered dynamics, negotiation and adaptation that are part of the experiences of Sikh migrants in Spain. Santos-Fraile especially attends to novel forms of agency among young Sikh women in Barcelona in terms of Sikh identity construction, kinship/marriage patterns, body/corporeal (re)presentations and self-reflexivity vis-à-vis the process of cultural socialization in Spain.

\section{Deconstructing Sikh Masculinities}

In his ethnographic study of Italian Sikh communities, Nachatter Singh Garha emphasizes how Sikh masculinities are constructed through notions of what constitutes Sikh masculinity transferred from the homeland, as well as those subsequently developed within the Italian context. According to Singh, gender construction for Sikh males is directly influenced by their perceptions of control or lack thereof over their wives. Women who have higher education are less willing to give up their own rights in the interests of their husbands. This has led to new challenges for Sikh males, many of whom are struggling to construct viable versions of masculinity in a new social context.

Christine Moliner's work brings a layered ethnographic approach to the discussion of gender construction, in particular the negotiation of Sikh masculinity in France. The majority of Sikhs in France have stemmed from rural backgrounds and most arrived through widespread transnational connections. Moliner's primary focus, however, is instead on the impact of immigration policies on young undocumented Sikh migrants arriving in Paris through illegal means, including immigration smugglers' contacts. This shift in connections has greatly impinged these new migrants' social and economic incorporation processes in Paris. The notion of $i z z a t / p r i d e$ figures significantly in their struggles against their subordinate status. Migrants' constraints and challenges stem from biases and prejudices that they experience from the wider French community, but also the negative attitudes afforded them from their fellow French Sikhs, especially regarding economic advancement. Gurdwara politics, relationships and practices, both inclusionary and exclusionary, are also examined from the perspective of these undocumented migrants.

In his article on the notorious late Punjabi Sikh gangster, Bindy Johal, Manjit Pabla adds an important gendered complexity to this volume in examining competing dimensions of masculine gender construction. Johal's legacy is both filtrated with heroism but also insidious characterizations-Johal as folk devil. Narratives surrounding Bindy Johal 
have contributed to continuing gang violence stemming from the Greater Vancouver Sikh community. Pabla traces these conflicting narratives within the context of a 'contemporary moral panic' over hyper-masculinity, gang involvement and the prevailing challenges faced by racialized, working-class boys and men.

\section{History, Text, Theory}

It is in the disciplines of history, textual studies (including scripture) and theology that scholarship within Sikh Studies has generally been most easily situated. It is in these arenas that most scholarly works on Sikh traditions have developed and thrived. The wide-ranging chapters on offer here attest to this richness. Robin Rinehart's work is an exegetical and historical exploration of the gender and the Dasam Granth, a scriptural text second only to the Adi Granth/Guru Granth Sahib in its importance. As Rinehart notes, the Dasam Granth has long been embroiled in controversy in terms of its authorship and the inclusion of narratives steeped in Hindu mythology. She examines the figure of the Devi or Durga, interpreted by Sikhs instead as "sword" instead of goddess. As a result, Rinehart maintains that Sikhs have thus lost their direct association with the feminine divine. She also examines one of Granth's central narratives, 'the nature of women' or 'the wiles of women'. Regarding the well-known (and generally negative) tropes of women's nature, Rinehart observes that there is no generic and comparable 'male nature' that comes to the fore through these narratives. In terms of developing approaches to the Dasam Granth, women's voices are increasingly complementing — and at times challenging-male interpretations that have largely prevailed, whether within scholarly or popular realms.

Satwinder Kaur Bains interrogates gender difference and Sikh feminisms through Sikh theological perspectives, scripture references and prescriptive texts. Bains examines how Sikh feminist approaches deconstruct politics of power and create interpretive spaces within which to question both misrepresented and misinterpreted texts. She focuses extensively on uncovering gender differences in practice and ideology vis-à-vis the five Ks, external markers and outward representations of Sikh identity.

Eleanor Nesbitt offers a novel study of gender construction and representation of Sikh women through the colonial "gaze", particularly through an uncovering and analysis of the writings of western women travelers, army wives, missionaries, artists among others in the nineteenth- and early twentieth centuries. Not surprisingly, these colonial accounts were heavily weighted in favour of "race" (white women of the ruling class) over that of gender commonality with Sikh women. Moreover, notions of Sikh women's identity are noted as problematic by Nesbitt, given that they were identified as Sikh vis-à-vis their relations to Sikh menfolk. These accounts included a "spectrum of gazes", both approving and disapproving of Sikh women's realities.

Nicola Mooney utilizes a gendered lens to examine the gaps between deeply held and celebrated Sikh notions of egalitarianism and the lived experiences of Sikhs, especially vis-à-vis Anshu Malhotra's notion of the "shameful continuities" (Malhotra 2010) of gender and caste-based hierarchies in contemporary Sikh attitudes and practices. She delineates the space between "the ideal and the real" as "third spaces" that are particularly instructive for both analysis and critique in attempting to understand contemporary Sikh subject formation. While highlighting the promise (and paradox) of Sikh egalitarianism scripturally and theologically, Mooney focuses most specifically on Sikh practices of householding as primary intersections of caste and gender, those "prosaic — and deeply unequal" as sites of kinship. Gurdwara reform, according to Mooney, regarding gender and caste-based inequities may be inadequate unless the unequal and ongoing domestic kinship practices are addressed.

Jaspal Kaur Singh's article examines female construction within various contemporary Sikh diasporas through an analysis of a selection of creative and non-fiction writings and testimonial life writings. Singh analyzes central Sikh tenets and religious practices, some deeply personal, and many steeped in patriarchal traditions, examining how they are 
resisted, reinterpreted and reconstructed through these varied writings as expressions of agency, gender negotiation and practices within Sikh diasporic spaces.

\section{Gendered Performance, Aesthetics and Economics}

Anjali Gera Roy's work focuses on the gendered nature of Punjabi dance, most particularly the traditional male genre known as bhangra, and examines its unmistakably masculine, warrior and peasant-inspired movements, alongside what Roy delineates as its accompanying "lyrical machismo". She also locates the connection between bhangra and Sikhs, through the dance form's agrarian origins and traditional Jat Sikh symbolic association with the "land", notions of hypermasculinity and Sikh male devotional bodily signifiers, particularly the turban. Roy examines the incursion of a small number of female musicians who have been able to "make a dent in the male bhangra monopoly", with a particular focus on female rapper Hard Kaur, who deconstructs the segregated male bhangra space, then blends elements of traditional masculine and feminine tropes through co-option and challenge to Punjabi/Jat/Sikh patriarchies.

Zabeen Khamisa closes this Special Issue by adding an important dimension to Sikh gender production through her examination of Millennial Fashion Enterprises in Canada, identified as "Sikh chic". She delineates these enterprises as values-based in terms of self-determined representation, ethical purchasing, and gender equitable, all the while steeped in the free-market economy and the digital marketplace. While the normative Khalsa Sikh male aesthetic has long been steeped in tradition, young Sikh women are moving to the frontlines in challenging mainstream representations of Sikh masculine identities, but also in creating new aesthetic and fashion platforms that reflect the lived experiences of women or "Kaurhood".

As will be shown throughout this issue, with the expansion of the boundaries defining "what is religion" and "what counts" as important aspects of rich Sikh traditions, alongside diverse approaches to constructions of gender, this Special Issue is a significant, perhaps even groundbreaking contribution to Sikh Studies.

Funding: This research received no external funding.

Conflicts of Interest: The author declares no conflict of interest.

\section{References}

Bailey, Michael, and Guy Redden, eds. 2011. Religion as a Living Culture. In Mediating Faiths: Religion and Socio-Cultural Change in the Twenty-First Century. Farnham: Ashgate, pp. 1-24.

Brah, Avtar. 1991. Questions of difference and international feminism. In Out of the Margins. Edited by Jane Aaron and Sylvia Walby. London: Falmer Press, pp. 168-76.

Chidester, David. 2000. Material Terms for the Study of Religion. Journal of the American Academy of Religion 68: 367-80. [CrossRef]

Crenshaw, Kimberle. 1991. Mapping the margins: Intersectionality, identity politics and violence against women of color. Stanford Law Review 43: 1241-99. [CrossRef]

Fiorenza, Elisabeth S. 1990. Changing the Paradigms. Christian Century 107: 796-800. Available online: http:/ / www.religion-online. org/showarticle.asp?title=439 (accessed on 1 March 2017).

Hall, David, ed. 1997. Lived Religion in America: Toward a History of Practice. Princeton: Princeton University Press, pp. viii-ix.

Jakobsh, Doris R. 2003. Relocating Gender in Sikh History. In Transformation, Meaning and Identity. Delhi: Oxford University Press.

Jakobsh, Doris, ed. 2010. Sikhism and Women: History, Texts and Experience. Delhi: Oxford University Press.

Malhotra, Anshu. 2010. Shameful Continuities: The Practice of Female Infanticide in Colonial Punjab. In Sikhism and Women: History, Texts and Experience. Edited by Doris R. Jakobsh. Delhi: Oxford University Press, pp. 83-114.

Moi, Toril. 2015. Thinking Through Examples. What Ordinary Language Philosophy Can Do for Feminist Theory. New Literary History 46: 191-216. [CrossRef]

Singh, Nikky-Guninder K. 1993. The Feminine Principle in the Sikh Vision of the Transcendent. Cambridge: Cambridge University Press. Singh, Nikky-Guninder K. 2005. The Birth of the Khalsa. A Feminist Re-Memory of Sikh Identity. Albany: SUNY Press. 